\title{
DETERMINANTS OF FOREIGN INSTITUTIONAL INVESTMENT IN INDIA: AN EMPIRICAL ANALYSIS
}

\author{
SRINIVASAN P. \\ Christ University, Karnataka, India \\ E-mail: srinivasaneco@gmail.com \\ KALAIVANI M. \\ MGR Art \& Science College, Krishnagiri, \\ TamilNadu, India \\ E-mail: kalaivani_eco@yahoo.com
}

\begin{abstract}
The purpose of the study is to explore the determinants of foreign institutional investments in India through the Autoregressive Distributed Lag (ARDL) bounds testing approach. Using quarterly time series data, the empirical analysis was carried out for the period from January 2004 to December 2011. Our study result shows that exchange rate has significant negative impact on FII inflows both in the short-run and long-run, implying that depreciation of currency adversely affects the FII flows into India. Moreover, the Indian equity market returns has negative short-run and positive long-run effects on FII inflows to India. This confirms the evidence of positive and negative feedback trading hypothesis in the short-run and long-run, respectively. The US equity market returns has positive and significant influence on FII flows in the long-run but positive and insignificant influence on FII flows in the short-run. The risks associated with US equity market encourage foreign institutional investors to invest more in Indian equity markets. Furthermore, domestic inflation exerts negative and positive significant influence on FII flows in the long-run and short-run, respectively. It can be concluded that FII inflows to India are essentially determined by exchange rate, domestic inflation, domestic equity market returns, returns and risk associated with US equity market.
\end{abstract}

Keywords: FII inflows, stock market, Exchange rate, Inflation, ARDL-UECM, Cointegration

JEL classification: C22, F31, F32. 